\section{SOME AVIATION GROWTH EVENTS}

\author{
M Leroy Spearman* \\ NASA Langley Research Center \\ Hampton, Virginia 23681
}

\section{$\underline{\text { Abstract }}$}

The growth of aviation since the first flight of a heavier-than-air powered manned vehicle in 1903 has been somewhat remarkable. Some of the events that have influenced this growth are reviewed in this paper. This review will include some events prior to World War I; the influence of the war itself; the events during the post-war years including the establishment of aeronautical research laboratories; and the influence of World War II which, among other things, introduced new technologies that included rocket and jet propulsion and supersonic aerodynamics.

The subsequent era of aeronautical research and the attendant growth in aviation over the past half century will be reviewed from the view point of the author who, since 1944 , has been involved in the NACA/NASA aeronautical research effort at what is now the Langley Research Center in Hampton, Virginia. The review will discuss some of the research programs related to the development of some experimental aircraft, the Century series of fighter aircraft, multi-mission aircraft, advanced military aircraft and missiles, advanced civil aircraft, supersonic transports, spacecraft and others

\footnotetext{
* Senior Technical Specialist Systems Analysis Branch Associate Fellow, AIAA Copyright (c) 2002 by the American Institute of Aeronautics and Astronautics, Inc. No copyright is asserted in the United States under Title 17, U.S. Code. The U.S. Government has a royaltyfree license to exercise all rights under the copyright claimed herein for Governmental purposes. All other rights are reserved for the copyright owner.
}

AIAA 2002-0172

$\underline{\text { Introduction }}$

Orville and Wilber Wright were credited with achieving the first flight of a heavier-than-air, powered, man-carrying airplane at Kitty Hawk, North Carolina, USA on December 17, 1903. This event marked the beginning of a dramatic history of aviation growth. The airplane has changed from a curiosity to a vehicle of many uses that include transportation, exploration, recreation and warfare. The growth in aviation has occurred in many countries around the world and has been fostered by the native talent of individuals as well as by the exchange of information between countries and by the import and export of hardware. Driving factors in this growth have included the innate curiosity of man, an inherent desire for adventure, the quest for economic benefits, and the feeling of need for security and superiority.

\section{$\underline{\text { Discussion }}$}

The Beginnings. The Wright's achievement of manned, powered, controlled, heavier-than-air flight in 1903 was preceded by many years of thinking, planning, and working. The Wright's could also benefit from the works of several other's. One of the first to concentrate on the development of a heavier-than-air, fixed-wing flying machine was Sir George Cayley of England. In 1853, Cayley made a glider in which it is said that his unwilling coachman made what was probably the first flight in a manned, heavier-than-air craft. While Cayley was laying much of the foundation for modern aircraft, he could not provide what he called a prime mover - a suitable lightweight engine.

Among other innovative glider designers was Otto Lilienthal, a German, who, in the 1890's built and flew many successful hang-gliders. Lilienthal was killed in 1896 when a wind gust caused the glider on which he was flying to stall and crash. Lilienthal did record his work so that others might benefit from his experience. One follower, Percy Pilcher in Scotland, constructed several promising gliders in the late 1890's and was working toward a powered machine when a crash ended his career. In the United States, a French-born American, Octave Chanute, became interested in aeronautics and flight. He wrote 
several journal articles on the development of the flying machine and in 1894 the articles appeared in book form entitled Progress in Flying Machines. Chanute and his associates did design, build and fly several modified versions of the Lilienthal-type glider. In about the same period of time in the late 1800's another American scientist, Samuel Pierpoint Langley became convinced that powered flight was achievable. Langley did not experiment with gliding flight but with models powered with rubber bands at first and then with steam engines. In November 1896, his steam-powered Aerodrome No. 6 successfully demonstrated powered flight when it flew for three-quarters of a mile before running out of fuel. The Wright brothers were aware of Langley's experiments and wrote for more information on his work. The Wright brothers also wrote to Chanute and described some of their experiments to him. This was the beginning of a friendship during which Chanute provided assistance and encouragement to the Wright's. The Wright's studies also included the work of Lilienthal.

While gliding flight demonstrated manned, heavier-than-air flight, a satisfactory engine to provide powered flight was needed. Some early attempts for powered flight were made using steam engines to drive a rotor or propeller but none were successful in achieving sustained, controllable flight. Langley did proceed from his powered flight success to an attempt to fly a manned version of the Aerodrome. He was dissatisfied with steam power because of the low power-to-weight ratio and had changed to an internal combustion gasoline engine similar to that being used on early automobiles. An attempt was made on Oct.7, 1903 to achieve mannedpowered-flight with the Aerodrome but it crashed immediately due to a problem attributed to the catapult launch mechanism. Another attempt was made to fly the manned-powered Aerodrome on Dec. 8, 1903 but again a crash attributed to the catapult launch occurred. Nine days later on Dec.17, 1903, Orville Wright successfully achieved powered flight at Kitty Hawk, NC. The Wright's had also turned to the gasoline-fueled internal combustion engine and had built their own engine based on the type being developed for automobiles.

Manned-powered-flight was now a reality. Man's innate curiosity had sparked the desire to fly. Gliding flight had demonstrated the theory of aerodynamics and lead to means of stability, control, and balance. The development of the lightweight internal combustion reciprocating engine completed the approach to manned flight. The reciprocating engine is still in use today and was essentially the only type of airplane engine for more than 40 years before the turbojet engine was perfected.

The Concept Spreads. A French artillery commander, Captain Ferdinand Ferber became interested in flying because of the exploits of Lilienthal and Chanute. In corresponding with Chanute, Ferber learned about the Wright's and began to correspond with them. Through his writings and lectures, Ferber had a significant influence on the advancement of flight in France. One early flyer in France was Brazilian-born Alberto Santos-Dumont who built and flew gasoline-powered airships in the late 1800's, turned to gliders and then to powered airplanes. He earned the credit for making the first powered, manned aircraft flight in France in 1906. The Wright's finally demonstrated their airplane to the U.S Army and sold the first airplane to the Army in 1908. The Wright's also demonstrated in France to an enthusiastic audience. The first heavier-than-air machine to fly in England, the Army Aeroplane No.1, flew in October 1908. The machine, similar to the Wright design, was created by Samuel Cody, an American-born naturalized Briton. The first heavier-than-air flight in Germany was a 1908 demonstration by J.C.H. Ellehammer, a Danish visitor. The German's were intrigued with the rigid airships being built by Count von Zepplin and paid little attention to the airplane. In an effort to catch up, however, the German's were soon to borrow from France and from other's. Germany capitalized on the talent of Anthony Fokker, a Dutchman who came to Germany to study engineering. In Russia, a young designer, Igor Sikorsky, was experimenting unsuccessfully with helicopters. He then turned his attention to large, fixed-wing airplanes and produced what would become a forerunner of large bombers and commercial airplanes. Latter Sikorsky left Russia and came to the United States where he was to successfully produce helicopters. Following the initial success of the Wright Brother's, little attention was given to the airplane in the United States. Another U.S. designer, Glenn Curtiss, was becoming well known and a Curtiss airplane was the second airplane to be bought by the U.S. Army in 1911. 
The Airplane at War. The idea that an airplane might be used in warfare was adopted in the early 1900's by European countries where war was imminent. The French, the most air-minded in Europe, had 254 airplanes in the Army by 1912. Two prominent French designers's at the time were Louis Bechereau and Edouard Nieuport. Bechereau designed the Deperdussin racer in 1913 that was the first airplane to have a monocoque fuselage. Later he designed the Spad fighter of World War I fame. Nieuport was to become the designer of the famous Nieuport fighters of World War I. The British, after acquiring Army Aeroplane No.1, were slow in getting into military aviation. At the urging of such politicians as Winston Churchill, the Royal Flying Corps was established in April 1912. Some Among the British designers of the era where A.V. Roe, Geoffrey de Haviland, and T.O.M. Sopwith, each of who made important contributions to British airpower. In Germany the efforts of Fokker lead to the monoplane, biplane, and triplane fighter airplanes of World War I fame. The U.S. showed less interest in developing air power than did the European nations since the threat of war was less ominous. However, some interesting developments did take place. The Army produced the world's first bombsight and conducted live bombing tests from a Wright Flyer in 1911. In the winter of 1910-1911, the U.S. Navy conducted the first shipboard takeoff and landing with a Curtiss airplane. Curtiss airplanes were also used for catapult launch testing. In 1911, Curtiss produced a practical seaplane. With wheels attached to the seaplane, Curtiss also demonstrated the world's first amphibian. Curtiss went on to build a watertight fuselage and produced the world's first flying boat.

The U.S. was slow in building airpower. When war broke out in Europe in August 1914 the U.S. had a total of 23 airplanes for military use. In contrast, France had 1400, Germany had 1000, Russia had 800 and England had 400. By 1915, the U.S. was producing the Curtiss JN-4 Jenny that was used primarily as a trainer. Some European airplanes were also manufactured in the U.S. as an aid to the war effort and this provided valuable experience to American industry. In the World War I era, the U.S acquired several European airplanes including those of Spad, Nieuport, Sopwith, deHaviland, and Breguet. American airplanes, in addition to the Curtiss Jenny, included those of ThomasMorse, Packard-Le Pere, Standard, and Martin.
In the final days of World War I, Russia, in the midst of a revolution was also accumulating foreign aircraft and engines from various sources including French, German, British, Italian and Dutch. Soon after the war, the Russians also obtained the rights to build the U.S. Liberty engine. These acquisitions were of great value to the newly formed Soviet Union in establishing a base in aviation technology.

Between World War I and II. During the 1920 's and 1930's many nations were developing indigenous airplane types for both military and civil use. Among the producers in the U.S. were Curtiss, Boeing, Douglas, Martin, Lockheed, Keystone, North American, Consolidated, Ryan, Grumman, Bell, Vultee, Republic, Northrop, Vought, Sikorsky, Berliner-Joyce, Brewster, Stearman, Beech, Cessna, Fairchild, Seversky in Great Britian producers included DeHaviland, Bristol, Avro, Handley-Page, Fairey, Hawker, Supermarine, Armstrong-Whitworth, Blackburn, Westland, Saunders-Roe, Gloster, Boulton-Paul, Short, Bristol - in France producers included Leo, Breguet, Dewoitine, Farman, Amiot, Potez, Loire, Bloch, Morane-Saulner, Latecoere, Nieuport, Hanriot - in Germany producers included Focke-Wulf, Heinkel, Dornier, Arado, Henschel, Junkers, Messerschmitt, Fieseler, Blohm and Voss - in Italy producers included Caproni, Savoia-Marchetti, Fiat, Breda, CANT, Macchi, Piaggio - in Japan producers included Mitsubishi, Kawaski, Nakajima, Aichi, Showa, Kawanishi, Hiro - in the Netherlands producers included Fokker, Koolhoven - in the Soviet Union producers included Antonov, Beriev, Ilyushin, Lavochkin, Lisunov, Guryevich, Mikoyan, Myasishchyev, Petlyakov, Polikarpov, Sukhoi, Tupelov, Mil, Yakovlev, Bratukhin, Kamov, Kalinin .

Some technology transfer between nations occurred in the 1920's and 1930's through the interchange of hardware. Junkers of Germany operated a plant in the Soviet Union from 1923 to 1927 as a way for Germany to overcome some of the restrictions imposed by the Treaty of Versailles and as a way for the USSR to accelerate their aircraft technology in areas such as the use of duralumin in the design and construction of metal, cantilever wings. Some European designed airplanes found a place in the growth of U.S. aviation - for example, the Dutch Fokker T-2, a single-engine, cantilevered highwing monoplane was used by the Army Air Service and made the first non-stop flight across 
the U.S. in 1923. The Fokker C-2 trimotor transport, also used by the Army Air Service, was used by Admiral Byrd in a flight over the North Pole in 1926 and by the Army in the first California to Hawaii flight in 1927. The Fokker trimotor also saw early airline service in the U.S. preceding the Ford Trimotor.

Thus a considerable amount of aviation technology was transferred between nations in the 1920's and 1930's through the interchange of hardware. Another source of aeronautical technical information was beginning to become prominent during the 1920 's. This was the creation of aeronautical research laboratories by many governments for the purpose of achieving preeminence in aviation. In the United Stares, the National Advisory Committee for Aeronautics (NACA) was created by an act of Congress in 1915 and the first NACA wind tunnel was running at Langley Field, Virginia in June 1920. In Russia, the Central AeroHydrodynamic Institute (TsAGI) was established in December 1918. In Great Britain, the Royal Aircraft Establishment (RAE) was begun and, in France, a research center was started at Villacoublay. The NACA was quite prolific in the time period between World War's II and I in producing reports of investigations in many areas of aeronautical research. Among the results reported were those related to airfoil sections; drag cleanup; high lift devices; the NACA cowling; the engine supercharger; stressed-skin construction; cantilevered wings; retractable landing gear; enclosed cockpit; propellers; stability and control; boundary layers; dynamic stability; flying qualities and so on. These developments were directed toward increased efficiency; increased speed; increased safety and comfort; increased utility and productivity.

Civil aircraft development in the U.S. was delayed by World War I. Some airplanes used in early airline service were open cockpit, singleengine biplanes such as the Douglas M-2 and the Boeing Model 40. Among the first of the dedicated airliners was the Ford 2-AT, singleengine, all metal, high-wing monoplane with an enclosed cabin. This was followed by the Ford 4-AT, all-metal, tri-motor with an enclosed cabin for 11 passengers (the author of this paper made his first flight on a Ford Trimotor at the age of 16.) Before the trimotor was produced, Henry Ford's interest in aviation was noted in the development of a small, 350-pound, roadable, single-place aircraft referred to as the "sky flivver". At least three versions of the flivver were built and flown but it never reached the public. Other early civil transports included the Boeing Model 80-trimotor biplane and the Curtiss Condor twin-engine biplane. In the 1930 's some transports using more advanced technology began to appear. One of the these was the Boeing Monomail which first flew in 1930. The Monomail was a single-engine design that had a smooth, low, cantilever, all-metal monoplane wing, a cowled engine and a retractable landing gear. This was followed in 1933 by the Boeing 247, a twin-engine design with cowled supercharged engines, hydraulically controlled variable-pitch propellers, a low allmetal cantilever monoplane wing and a retractable gear. Also in 1933, Douglas produced the DC-1 that was followed by the DC- 2 and DC-3. These were all-metal designs with twincowled engines, a low cantilever monoplane wing, retractable gear, and variable-pitch propellers. The DC-3 was faster than the 247 and carried more passengers and thus was able to capture most of the domestic air transport market by 1940 .

A notable transfer of technology occurred in the mid 1930's when the U.S. permitted Soviet Union technicians to visit the Douglas Aircraft Company to examine the revolutionary DC-3 airplane. Subsequently, manufacturing rights were granted to the USSR where the airplane was produced under the direction of B.P.Lisunov as the Li-2. The Li-2 was soon placed in military and civil service where it remained until well into the 1940's.

In the 1930's, several clean streamlined airplanes were produced in the belief that there was a market for a small, high-speed transport. Included in this category were the Lockheed Vega and Orion, Northrop Alpha and Gamma, Vultee V-1A, and the Lockheed10/14/18 family.

Another event in the 1930-1940 time period was the flying-boat activity. These relatively large aircraft were primarily to support the oceanic routes of Pan American Airways. They included the Sikorsky S-38, S-40, S-42, Martin M-130 and Boeing 314. The flying boat concept was later replaced by large, new land-based airplanes.

Over 800 civil aircraft types were certified by the CAA in the U.S. from the mid 1920'5 to the 
mid 1950's. Among these were airplanes from Aeronca, Arrow, Beech, Bellanca, Bird, Boeing, Budd, Buhl, Cessna, Culver, Curtiss, Douglas, Erco, Fairchild, Fleet, Fokker, Ford, Gee-Bee, Great Lakes, Howard, Inland, Kellett. Kinner, Laird, Lockheed, Loening, Luscombe, Martin, Monocoupe, Mooney, Northrop, Piper, Pitcairn, Porterfield, Rearwin, Republic, Ryan, Sikorsky, Spartan, Stearman, Stinson, Swallow, Taylor, Travel Air, Verville, Waco and many others.

Military aircraft of various types were under development in the U.S. between World War I and II. Biplanes were prevalent in the 1920 's as the U.S. was following World War I designs. Army aircraft of that period included the Consolidated primary trainers, the Curtiss PW-8 Hawk family, Boeing PW-9, Martin MB-2, the Keystone bombers, Curtiss Condor, Curtiss O-1 and A-3, Douglas O-2, O-25 and O-38. The Boeing Company, in a private venture, began the development of a new biplane fighter in 1928 by changing from the liquid-cooled engine of the PW-9 to an air-cooled radial engine. The airplane was purchased by the U.S. Navy as the F4B-1 shipboard fighter. Based on enthusiastic Navy reports, the Army tested the airplane and bought it as the first of a long line of P-12's.

Monoplane designs became more prevalent in the 1930 's with the expectation that the performance would exceed that for biplanes. An early Boeing design designated XP-9 had a high, body-mounted, strut-braced wing. The XP-9 had an all-metal structure and a semi-monocoque fuselage that was to set the pace for future designs. The wing location limited the pilot's visibility and the airplane was not produced. The next monoplane effort by Boeing was the XP-15 which was essentially a P-12 with the lower wing removed. The XP-15 was never produced. The next Boeing monoplane design was the P-26, which had a wire-braced low wing, an open cockpit and a fixed gear. The P-26 was accepted and was a front-line fighter until the early 1940's. The follow-on fighter's to replace the P-26 were the SeverskyP-35 and the Curtiss $\mathrm{P}-40$. Some monoplane observation airplanes produced by Douglas were the O-43 and O-46. New monoplane bombers that appeared were the Boeing B-9 and the Martin B-10.

Once again in the 20th century, warfare was to play a part in the growth of aviation. In 1939, the United States had an air strength of about 1700 airplanes of which only about 800 could be considered first- line. These were primarily outdated Douglas B-18's, Curtiss P-36's, and Northrop A-17's. By contrast, the British had about 2000 first-line airplanes. French air power had deteriorated badly following World War I and the French had adopted a homeland defense policy to prohibit invasion that was based on heavily fortified fixed ground bases such as the Maginot Line. In Germany, where a military buildup had been underway, the Luftwaffe had at least 4000 essentially new airplanes. While the Western world was debating over the German buildup, another unusually large buildup was going on almost unnoticed on the small islands of Japan. The Japanese Air Force had about 2100 airplanes in 1937 and Japan was building two aircraft carriers yearly in the late 1930 's. The German might was unleashed in Europe in September 1939 and the Japanese attacked the U.S. in December 1941.

The U.S. airpower continued to grow in the late 1930's and early 1940's. Among the airplanes that appeared were the Seversky P-35, the Curtiss P-36 and P-40, the Boeing B-17 and B-29, the Consolidated B-24, the North American B-25, the Douglas A-20, the Douglas A-26, the Martin B-26, the Bell P-39, the Lockheed P-38, the Republic P-47, Northrop P61, and the North American P-51. American industry accelerated to meet the wartime demands. A prewar rate of 2000 airplanes per year was up to 4000 airplanes per month by 1943. In the years from 1940 to 1945 , the Air Forces accepted almost 230,000 airplanes

The rapid growth in aviation was paced by a growing need for an expansion of the research effort. The NACA laboratory at Langley Field was being stretched to the limit by the late 1930's. To aid in expanding the research effort, new NACA research centers were established in California (Ames in 1939) and in Ohio (Lewisnow Glenn in 1940). During the World War II years, the workload changed and increased. Attention was turned to the short-term problems of airplanes already in production as well as to exploring new fields of knowledge for those airplanes still under design. During the years from 1941 to 1944, the NACA laboratories worked on 115 different airplane types with spectacular results. Fighter speed, altitude, and maneuverability were increased; buffet, stall and spin problems were cured; bomber range and payload was increased. Many outstanding wartime airplanes were based on fundamentals 
developed by NACA - such as airfoil sections; cooling methods; high lift devices and so on. Many of the wartime developments were also to be used in commercial airplanes.

The American designed and built airplanes of World War II were generally produced in response to Army requirements. One exception, however, was the North American P-51. This airplane came about in response to a British search for a fighter airplane to replenish the dwindling Royal Air Force fighter strength. One of the American companies approached by the British, North American Aviation, Inc., undertook the design of the NA-73 airplane that was produced in 117 days. The airplane used a newly developed NACA laminar flow low-drag wing section and a radiator ingeniously positioned for low drag. The airplane was at first ignored by the U.S. Army but was later to be tested, accepted, and procured and, as the P-51 Mustang, became one of the outstanding fighters of its day. First powered with a U.S. Allison engine, the airplane was equipped by the British with a Rolls-Royce Merlin engine, which resulted in substantial increases in speed, range, and altitude.

Another type of technology transfer accelerated the growth of aviation in the Soviet Union. Under the Lend-Lease program the Soviets received over 18,000 airplanes - including the Bell P-39 Airacobra and Curtiss P-40 Tomahawk from the U.S. as well as some British Spitfires and Hurricanes. In addition, the Soviets received machine tools and factories including an aluminum rolling mill; 2.25 million tons of steel; 400,000 tons of copper; and 250,000 tons of aluminum (equal to 2 years of production at 1945 Soviet rates). All of these materials permitted the Soviets to change from wooden to metal airplanes late in the war.

Post World War II. - Much transfer of aviation technology followed the end of World War II. The Soviet Union, for example, began to study captured and interned airplanes of both friend and foe. One example was the exploitation of an American Boeing B-29, three of which had made forced landings in the Far East in 1944. A Tupolev design team dismantled the B-29 and copied the components and in 1947 the Soviet copy, designated the Tu-4 (NATO Bull), was shown in the Tushino Air Show. The Soviets acquired much in the way of airplane design and jet engine technology from the Germans. More jet engine technology was acquired from the British. The Soviets produced two British jet engines under license. Thus the early Soviet jet aircraft were powered by German and British engines.

Further growth in commercial transports began in the late 1930's and continued into the 1950 's after an interruption caused by World War II. Douglas had begun the development of the DC-4, a 4-engine enlarged version of the DC-3. The airplane entered military service as the $\mathrm{C}-54$. Lockheed developed the 4-engine Constellation that also saw military service. Other civil derivatives of the military were the Boeing 307 Stratoliner 4-engine transport developed from the B-17 bomber and utilizing, for the first time, a pressurized fuselage. Boeing also developed the 377 Stratocruiser a 4-engine transport derived from the B-29 and B-50 bombers. The 377 had a twin-lobe 2-level cabin.

Following the war, in 1945, a team of American scientists visited Europe to survey the state of technology related to aviation. Soon large quantities of scientific information was flowing in to the U.S. In addition, a number of scientists and technicians from Germany and Italy came to work in the U.S. Probably the most impressive new technology had to do with high-speed aerodynamics and included data on jet and rocket propulsion and on airframe shaping. Jet propulsion for airplanes was under development in Germany (von Ohain) and in Great Britain (Whittle) in the 1930's and 1940's. The German's were flying jet-propelled airplanes before the end of the war (He-178, Me-262) and the British twinjet Gloster Meteor was in service by the end of the summer in 1944. The U.S. began the secret development of a jet airplane in 1941 using an American version of the Whittle engine. The airplane, the Bell P-59 Airacomet first flew in October 1942.

The increase in airspeed made possible by the jet engine lead to studies of airplane shapes with reduced drag. One method was through the use of wing sweep that would delay the onset of compressible flow. Wing sweep had been thoroughly studied in Germany. Basic airfoil theory for swept and yawed wings by Dr. Adolph Betz was published in 1935. Based on the work of Betz, a low-speed wind-tunnel study of the aerodynamic characteristics of swept and yawed wings of various planforms was undertaken at NACA Langley in 1944 - a study 
to which the author of this paper was assigned. This testing included planforms that were swept back, swept forward, skewed, M-shaped, triangular, rectangular and trapezoidal. Some flight results for sweptback wings were also obtained at NACA-Langley in 1947 using the Bell L-39 research airplane. The L-39 was a Bell P-63 modified to accommodate a swept wing. The use of wing sweep in many countries was to have a pronounced effect on the design of aircraft for years to come. The first operational swept-wing fighter airplane in the U.S. was the North American P-86 that flew in October 1947. The airplane began its life in 1944 as the straight-wing Navy jet XFJ-1 Fury. As the swept wing data became available, the design evolved to the 35 degree swept wing.

Further growth in civil transports occurred following the war with the application of jet propulsion and wing sweep. The Boeing 707, the first jet transport in the U.S., flew in 1954. The 4-jet, swept-wing design was a private venture of the Boeing company based on the B-47 and B-52 swept-wing, jet bombers. The Douglas DC-8 was the second U.S. 4-jet swept wing transport. Convair also produced a 4-jet swept wing transport but production was limited because Boeing and Douglas took the market.

Another approach to low-drag wings was the use of delta shaped planforms with a highly swept leading edge and a low thickness ratio. Research on delta wing designs had been done in Germany by Lippisch. Lippisch came to the U.S. after the war and, working with the Air Force and Convair, aided in the design of the tailless delta airplane XF-92A which, in turn, lead to the Convair F-102, F-106 and B-58 delta wing airplanes. Many delta wing designs have been developed in many other countries.

Further studies of the use of wing sweep lead to the concept of variable sweep to combine the low-speed advantages of low-sweep with the high-speed advantages of high sweep into one airframe. The concept lead to the development of the Bell X-5 variable sweep research airplane. Further impetus for variable sweep research came in the mid 1950's when the British designer Barnes Wallis shared his concept of a variable sweep airplane, the Swallow, with John Stack of NACA-Langley. This lead to a series of wind tunnel studies of the use of variable sweep on transports, fighters and bombers. Among the purposes envisioned were for the commercial supersonic transport; the Navy combat air patrol (CAP); the Tactical Air Command (TAC) low altitude penetration; and the multipurpose commonality airplane directed by Secretary Robert McNamara for the Navy and the Air Force - the Tactical Fighter Experimental (TFX) which lead to the F-111. While the fundamental purpose of developing a multi-service airplane for the Air Force and the Navy was not successful in the TFX program, there have been other cases where commonality was achieved. Examples are the Boeing F4B Navy fighter and P-12 Army fighter; the McDonnell F4H Navy fighter that was later adopted by the Air Force as the F4.

The research airplane program that was begun in the late 1940's proved to be an effective way to advance the growth of aviation insofar as actual flight hardware is concerned. Before the advent of transonic wind tumnels. Early testing in the transonic range was sometimes done with free-flight rocket models; with the wing-flow technique; and with the transonic-bump technique. Early transonic data were obtained for what was to become the X-1 airplane by testing a half-model mounted on a curved bump on the floor of the Langley High-Speed 7-by-10-Ft. wind tunnel. When new hypersonic, supersonic and transonic tunnels became available, experimental data was obtained to accelerate the flight research program as well as the development of various types of missiles. launch vehicles and spacecraft.

Advances in the understanding of supersonic aerodynamics was underway in the 1950 's with the era of the 'Century Series' airplanes. The distribution of volume and weight with most high-speed jet designs was such that problems of inertia coupling and longitudinal and directional stability and control were encountered. The attainment of low drag was also a concern. These concerns lead to the development of the area rule for drag improvement and various tail arrangements for stability and control improvements.

The development of aircraft after World War II proceeded at a rapid rate. New missions were developed that required new aircraft types. At the same time, new types of aircraft were developed that suggested new missions. The advent of the high-speed computer has changed the design and analysis cycles and, when properly used in conjunction with experimental 
techniques, the development of aviation systems should become more accurate.

In the late 1950's and early 1960's, the quest for still further increases in productivity for civil transports continued. Attention was given toward increasing the speed or increasing the size of aircraft. Supersonic research had been underway at NACA following World War II. A research program on the supersonic commercial air transport (SCAT) began at the renamed NASA in 1959 and over a period of about 7 years studies were made of about 40 configurations. In 1963 a National Supersonic Transport (SST) Program was created and the research continued. An industry competition to develop a SST was won by Boeing/General Electric in 1966. The Boeing design was plagued with problems and through a host of technical, economical, ecological, and political concerns, the U.S. SST program was cancelled in March 1971.

In the same time period that the supersonic transport studies were underway, other studies were being conducted by industry and the airlines to develop a larger subsonic transport. These studies were aided by an Air Force request for a large, long-range, logistic transport that resulted in the $\mathrm{C}-5$. Lockheed won the $\mathrm{C}-5$ competition and Boeing turned their attention toward the development of the 747 . The 747 retained the 4-engine, swept-wing design of the 707 but introduced the first of a new generation of wide-body jumbo jets. The 747 entered service in 1970 and continues in service to this day. Other jumbo jets that followed were the McDomnell-Douglas tri-jet DC-10 and the Lockheed tri-jet L--1011. Other jet transport have entered the market such as the Boeing 757 and 767 and several Airbus models. Only one supersonic aircraft has entered the commercial transport market thus far - the British-French Concorde that has been in service since1976.

\section{Epilogue}

Mankind has been upgrading the means and methods of transportation since time began. Methods of moving on land and water have been progressively improved for years. Progress in moving through the air has primarily been achieved just in the past century. While flight with lighter-than-air vehicles was accomplished earlier, it was the achievement of manned flight with a heavier-than-air powered vehicle that set the course of air transportation. Gliding flight was first mastered but the invention of a lightweight engine and propeller system is what it took to really get man off the ground. Since that event occurred in December 1903, aviation technology has grown significantly. The growth has been fostered by the interchange of ideas and people between many countries. The use of the airplane in warfare has caused rapid growth in aviation technology. A very significant event was the introduction of jet propulsion. The propeller-driven airplane was limited by the rotational speed of the propeller and jet propulsion open the way for a whole new bred of high speed aircraft. Jet propulsion coupled with improved design methods and with improved construction techniques have provided aircraft with capabilities that far exceed what might have been expected at the time of the Wright brothers flight in 1903. And the future, of course, is yet to unfold.

\section{Bibliography}

Spearman, M. Leroy: A Review of 50 Years of Aerodynamic Research with NACA/NASA. NASA TM 109163,1994.

Spearman, M. Leroy: The Evolution of the High-Speed Civil Transport. NASA TM 109089, 1994.

Spearman, M. Leroy: Historical Trend in the Research and Development of Aircraft. NASA TM 84665, 1983.

Spearman. M. Leroy: Historical Development Of Worldwide Supersonic Aircraft. NASA TM 85637, 1983.

Spearman, M. Leroy: Design Trends for Army/Air Force Airplanes in the United States. NASA TM 4179, 1990.

Spearman, M. Leroy: Before the High-Speed Civil Transport. Presented at the AIAA/AHS/

ASEE Aircraft Design, Systems and Operations Conference, Seattle, Washington July 31August 2, 1989.

Ellis, Paul: Aircraft of the U.S.A.F., Sixty Years In Pictures. Jane's Publishing Co. London 1980.

Prendergast, Curtiss: The First Aviator's. Time-

Life Books, Arlington, VA, 1986.

Wallhauser, Henry T.: Pioneers of Flight. Hammond Inc., Maplewood, NJ, 1969.

Boyne, Walter J.: The Smithsonian Book of Flight. Smithsonian Books, Washington, D.C. 1987.

Gunston, Bill: Aviation, The Complete Story of Man's Conquest of the Air. Octopus Books Limited, London, 1978.

Juptner, Joseph P.: U.S. Civil Aircraft Series. TAB AERO Division of McGraw-Hill, Inc. 
Blue Ridge Summit, PA. 